\title{
DR. QUINN, MEDICINE WOMAN AND THE PRIME-TIME “OUTING” OF WALT WHITMAN
}

\section{Desirée HeNDERSON}

THE QUESTION OF Walt Whitman's sexuality has long been a site of debate within Whitman studies. In the last ten years, this debate has gained renewed scholarly attention and been the central concern of a number of important works of Whitman criticism. ${ }^{1}$ In the wake of contemporary scholarly considerations of Whitman's life and works, the "question" of his sexuality has - at least for academics - often appeared to have been settled. Recently, Gary Schmidgall, in Walt Whitman: A Gay Life, has detailed the queer content of Whitman's biography, assuming with absolute confidence the fact of his homosexuality. Indeed, Schmidgall relegates the alternate opinion to a single sentence in a footnote: "Still, resistance to a homosexual Whitman continues to be encountered." 2 What is remarkable about the apparent ease with which Whitman scholars reference nineteenth-century homosocial communities, male friendships, and Whitman's own relationships is the discrepancy between such affirmations and the contested place of homosexuality and homosexual people in late twentieth-century American society. How do celebratory "outings" of Whitman relate to the violence that continues to surround the act of "outing" in contemporary culture? What does it mean that Whitman is increasingly called upon to embody homosexuality to a popular audience, for whom the declaration of sexuality is potentially threatening?

One place that this phenomenon is evident is in an episode of the popular television series Dr. Quinn, Medicine Woman. In this episode, Whitman's sexuality becomes the object of spectacular consumption. The episode demonstrates the difficulty of reconciling an affirmation of Whitman's homosexuality with the crisis provoked by the act of revelation. It is especially interesting that this issue would be addressed by a series committed to portraying "Family Values" on television. In its utilization of Whitman as the embodiment of homosexuality, Dr. Quinn, Medicine Woman attempts to mediate between Whitman's official and scandalous identities, while capitalizing upon both. Whitman is called upon to dramatize the irreconcilable tensions between tolerance and intolerance to the act of "outing." $\mathrm{He}$ is simultaneously sanitized as a non-threatening homosexual and sensationalized as a rehearsal of con- 
temporary fears about gay men, which are mediated across the poet's body. His presence in this episode provokes a consideration of the intersection between identity and revelation, the problem that Whitman continues to represent despite all that has been said and all that will be said about his sexuality.

Dr. Quinn, Medicine Woman is set in Colorado Springs in the 1870s, a border space between the civilized east and the wild west. Dr. Quinn, a female doctor, travels to the idyllic town to set up her medical practice. In the course of the show, Dr. Quinn acquires a family and a husband and comes to act as both the conscience and civilizing agent of the small town. The series integrates historical events and figures into its stories-George Armstrong Custer, Ulysses S. Grant and Annie Oakley have all visited the town at one point or another. These famous characters, as well as the weekly regulars, are used to dramatize conspicuously twentieth-century concerns (e.g., breast cancer, rape, racism, child abuse). At the same time, the show employs a curious combination of feminism and romanticism in which, for example, the main character is a strong, independent woman whose happiness is nonetheless determined by her makeshift traditional family. This blending of nineteenthcentury historical contexts, contemporary social issues and romantic story lines kept Dr. Quinn on the air for six seasons. (Dr. Quinn was recently canceled, but its syndication was immediately picked up by the self-declared "family friendly" PAX network.)

The episode with which we are concerned is entitled "The Body Electric," written by Christine Berardo and aired in 1997. In this episode, Whitman travels to Colorado Springs to recover from a stroke. In exchange for a public poetry reading, he is to receive a rest-cure at the local hot springs/hotel. Dr. Quinn becomes his physician, however, after the resort doctor refuses to treat Whitman. Dr. Quinn is concerned about Whitman's lagging spirits and innocently encourages him to send for his "true love." When Peter Doyle arrives, the entire town is forced to contend with the sexual content of Whitman's poetry made disturbingly real. Dr. Quinn herself faces a moral crisis because she had been a vocal advocate of Whitman's freedom of expression when she believed that he wrote about heterosexual love and desire. ${ }^{3}$ Whitman is threatened with being thrown out of the town, and his poetry reading is canceled. Dr. Quinn must reconcile her own fears about Whitman's sexuality in order to direct the proper response of the town and her family in the face of these actions. ${ }^{4}$

Dr. Quinn, Medicine Woman, like most melodramatic texts, depends upon the mobilization of character-types, characters who are identified by a single, often superficially visible, marker that is both their type and their internal being. For example, the fictional Colorado Springs has a single African-American couple, who are called upon to represent the entirety of experiences of post-Civil War African Americans. Likewise, 
the town is inhabited by the Mexican woman, the elderly man, the good prostitute, the bad saloon owner-a litany of types which are shuffled around to provoke weekly story-lines but which are invariably recognizable by their stable identities and markers. Within this script of types, Dr. Quinn clearly represents civilization, education and true femininity while her husband (the almost-Indian, Sully) represents nature, native knowledge and masculinity.

Whitman's entrance into the logic of the show troubles this typology. He is the embodiment of homosexuality, whose other characteristics (famous poet, elderly victim of stroke) are supplemental to this main identification. Yet, the episode dramatizes this structure of identification in the reverse, so that "we" (the audience and the inhabitants of Colorado Springs) view Whitman initially as the poet/stroke victim. In this way, his sexuality must be revealed, a tearing away of his superficial identity to uncover his gayness. At the moment of revelation, however, we are encouraged to understand that his homosexuality is Whitman's true self.

This structure of revelation is indebted in many ways to the contemporary phenomenon of "outing." As Eve Sedgwick describes in Epistemology of the Closet, the metaphor of the closet has laid hold of our cultural imagination and profoundly shaped our understanding of the function of privacy and disclosure, especially as it regards the intimate acts of the body and the construction of identity. Yet, as Sedgwick delineates, gay self-disclosure is a tricky business, in which "the potential injury goes in both directions," implicating the recipient of the revelation as well as the speaker. Of course, self-disclosure is not always a privilege reserved for queers; the act of revelation is often wrested from them quite violently, with equally violent effects. The process of "being outed" rather than "coming out" locates power with the speaker, whose ability to penetrate the secrets of another occurs outside the control and without the consent of the "outed" individual. The act of "outing" is, unfortunately, often the site around which popular pleasure accruesthe pleasure of viewing the spectacle of revelation. ${ }^{5}$

The spectacular nature of Whitman's identity in this episode is communicated through a trio of montages. As stated previously, the initial conception of Whitman is as a famous poet and a stroke victim. These characteristics are presented through a long montage sequence at the beginning of the episode. The news that Whitman is arriving on the train spreads as a rumor across the town. We see its reception by various citizens - the pastor, the owner of the local mercantile, the barber, etc.- as the camera ranges through the town, capturing the different responses this information provokes. This montage culminates with Whitman's arrival, the town gathered to welcome him. It is also at this moment that we have our first clue that something is amiss when the resort doctor refuses to shake Whitman's hand. All of these events oc- 
cur before the opening credits, firmly establishing both the essential facts of Whitman's character and the underlying hint of something hidden beneath his surface identity.

The action of the episode pursues this hidden information, which is ultimately communicated through the second montage sequence. The actual act of revelation is remarkably silent. It is never explicitly stated that Whitman is gay; rather the dialogue is steeped in vague nineteenthcentury clichés - Whitman is described as "peculiar," as "deviant," as "preferring the company of men," as a "nancy boy," and as a "sinner." This information circulates as another rumor, which we see repeated as a mirror of the initial montage. Yet, this proliferation of speech about Whitman's sexuality is actually empty of speech, as the dialogue is masked with music. For example, the moment that Dr. Quinn finally hears the "truth" about Whitman, we simply see another character lean in and whisper in her ear. It is her facial expression of shock and surprise that confirms the revelation. The absence of words, however, does not diminish the impact or consequences of the revelation. If anything, the characters' silence calls the audience into the secret-we must understand the nature of the revelation to read the silences. It is, however, not clear whether this silence indicates that Whitman's sexuality is generally known or that the audience simply knows by now that secret identities are invariably sexual ones.

It is, of course, significant that in neither of these montages does Whitman appear. Whitman does no work in the construction of either identity-neither the one that precedes him nor the one that follows him. In fact, Whitman is never given the opportunity to speak for himself. At a certain moment, after he tells Dr. Quinn he has sent for his "true love," he begins to say, "I should tell you ...." Dr. Quinn, however, interrupts him, and his announcement remains unspoken. In fact, Whitman is presented as resigned to having his sexuality designated by others. Throughout the episode, Whitman demonstrates an awareness of occurrences around him (as the rumor spreads) and responds with sad recognition. The crisis of the episode is not understood to be Whitman's (despite the consequences he suffers), but Dr. Quinn's.

Within Dr. Quinn, Medicine Woman's melodramatic structure, each episode presents a moral crisis that Dr. Quinn must resolve. In this episode, Whitman himself plays the function of the moral test-his very presence draws Dr. Quinn into the realm of dangerous sexuality. This dilemma is communicated by two opposing scenes from the show. In the first, prior to Whitman's outing, Dr. Quinn's son reads aloud from "Song of the Open Road":

Camerado, I give you my hand!

I give you my love more precious than money,

I give you myself before preaching or law; 
Will you give me yourself? will you come travel with me?

Shall we stick by each other as long as we live? ${ }^{6}$

With this text as a voice-over, the camera shows Dr. Quinn's husband riding up on his horse, jumping off and running to Dr. Quinn. They embrace and kiss. He says, "His poems say what I feel in my heart." She responds, "If only people could see that there's nothing to be afraid of." In this instance, Whitman's poetry is immersed in heterosexual love and desire, even sanitized by the legitimacy of the love represented.

The opposing scene occurs after Whitman's sexuality has been revealed to Dr. Quinn. Late at night, she sits anxiously reading Whitman's poems. She re-reads the same lines from "Song of the Open Road" to Sully, exclaiming, "he's talking about his camerado. His comrade. A man." Sully responds, "It's the same words as before." But for Dr. Quinn, the content of the poem has been radically altered, just as Whitman's identity and character have undergone a radical transformation. The pairing of these two scenes demonstrates how Whitman's identity as an American poet has been fractured by the fact of his sexuality. At the same time, Dr. Quinn's heterosexual love is called into question-if the poem means love between men, how can it represent her love for her husband? This is the "potential injury" of revelation, as the danger of homosexuality threatens to infect Dr. Quinn's perfect heterosexuality. Her struggle to reconcile her feelings about Whitman is, likewise, an attempt to come to terms with the nature of her own sexuality and, by extension, her own identity.

The moral crisis that Dr. Quinn suffers becomes centered around two issues, her responsibilities as a doctor and her responsibilities as a mother. Both issues, however, provide the ground for the importation of twentieth-century myths and fears about homosexuality. The first of these is Dr. Quinn's discomfort with the fact that, although she is Whitman's doctor and examined him physically, she did not "see" that he is gay. Her desire to read homosexuality as a physical flaw mirrors contemporary debates about whether or not being queer is a product of biology or psychology. The biological determinism argument characterizes the act of "outing" as a declaration of an essential, genetically determined truth rather than a question of choice or desire. The doctor from the hotel who had refused to treat Whitman visits Dr. Quinn and brings her a copy of a recently published article about homosexuality. The article claims that "sexual deviance may be a genetic default," under which individuals can neither help themselves nor control themselves. The treatment for such people, she is told, is to be placed in an asylum. What if, Dr. Quinn asks, it is not a question of genetic determination? Then, she is told, it is "a matter of will" and therefore enters into the realm of sin rather than sickness. 
This conversation underscores Dr. Quinn's tentative position between Whitman's doctor and his moral judge. The fact that she has been treating him for physical infirmities (his stroke) further implicates her in his need for a "cure." Indeed, Whitman's frail body is an indicator of his overall "illness"- a reductive script for the contagious gay body. The transference between Whitman's stroke and his sexuality is further suggested in a scene in which Dr. Quinn (now aware of Whitman's sexuality) examines Whitman. He says, ostensibly about his stroke and with his characteristic resignation, "Some things cannot be altered, dear Doctor. We must learn to accept them as they are." This cryptic statement cements the biological essence of Whitman's "infirmities" and offers Dr. Quinn a means of narrating Whitman's identity to herself. Both his sexuality and his stroke-ravaged body are incurable but natural effects of his essential self. The question remains one of acceptance on her part, rather than cure or recovery on Whitman's part.

The second issue that provokes Dr. Quinn's fears about Whitman's dangerous sexuality centers on her mothering role. Whitman makes friends with Dr. Quinn's son, Brian, and on two separate occasions is alone with him. Dr. Quinn's terrified response to these meetings draws upon contemporary (and misplaced) fears that equate homosexuality with pedophilia. Dr. Quinn's discovery that Whitman is gay is immediately followed by her discovery that he has been alone with her sonshock over the first revelation quickly turns to fear over the second. The fact that her responses follow one another so quickly naturalizes the association and allows the viewer to dwell in the possibility of her fear. This scintillating possibility is prolonged for dramatic purposes when Brian goes fishing alone with Whitman. When she finds out, Dr. Quinn's veneer of acceptance cracks and she rushes out into the woods to rescue her son. The dramatization of this moment extenuates the pleasure of the possibility - as Dr. Quinn rides through the woods, the background music is dark, ominous, and urgent, communicating the seriousness of the threat. In the end, of course, Dr. Quinn finds Whitman and Brian sitting side by side peacefully fishing and, in fact, discussing the rumors that have been circulating about Whitman. Brian asks him, "Are you a sinner?" Whitman replies, "Last time I looked the Good Book says we're all sinners." This oblique reply expands to include Dr. Quinn, hiding in the bushes and watching this exchange. Her expression of chagrin is also an expression of recognition. She has lost the fight between her fears and her better sense and has given in to the irrational and homophobic responses of her fellow citizens. She has been infected by the (other) sin of judgment, which goes against her role as the figurehead of tolerance and forward-thinking.

In the end, Dr. Quinn resolves her moral uncertainty about Whitman by arranging for the poetry-reading to take place. Noticeably, Dr. Quinn does not address the other threat Whitman faces: being thrown 
out of Colorado Springs. It is impossible, within this script of tenuous acceptance, that Whitman be allowed to stay. Nevertheless, the poetryreading acts as the narrative conclusion to the crisis of Whitman's sexual presence. In this way, Whitman is redeemed as the great American poet. With Whitman's return to his initial identity, Dr. Quinn is able to forgive or even forget his sexual identity. He is exonerated by his official status as "Poet." As a representative figure, Whitman can be (re)categorized into the melodramatic script of identity, and in this way contained, sanitized and romanticized. In the final montage sequence, Whitman reads aloud from a combination of "I Sing the Body Electric," "There Was a Child Went Forth" and "I Hear America Singing."

I hear America singing, the varied carols I hear . . .

The carpenter singing his as he measures his plank or beam,

The mason singing his as he makes ready for work, or leaves off work . . .

The shoemaker singing as he sits on his bench, the hatter singing as he stands. ...

$(2: 316)$

These lines from one of Whitman's catalogues of American scenes are a textual moment that is deliberately mirrored by the camera's movements. As he reads, the camera once again ranges through the town, showing scenes of idyllic nineteenth-century life - the blacksmith, barber, merchant, and preacher all going about their work. These scenes are incorporated into Whitman's voice-over, as Dr. Quinn, Medicine Woman lays claim to the weight of Whitman's American romanticism. The episode closes on the act of reading poetry in order to harness Whitman's symbolic role, a gesture that is at odds with the depiction of Whitman throughout. The third montage completes the framing narrative, enclosing the central revelation, and essentially ushering Whitman back into the closet of the American canon.

The incommensurate nature of this conclusion demonstrates the difficulty of representing Whitman's sexuality to a popular audience for whom even the historical distance and established personality of the American poet is an insufficient defense. It also reveals the uneasy relationship between a socially liberal but morally conservative agenda-as practiced by Dr. Quinn, Medicine Woman -in which a politically correct narrative of gay acceptance runs headlong into a conservative narrative of gay intolerance. The episode enacts in its structure, characterization, and dialogue the problems of a society that celebrates difference but fails to find any place for the different to reside or prosper. In Dr. Quinn, Medicine Woman, the conflict that Whitman embodies-the dangerous threat of secret identities and the impact of their revelation-is resolved through absence, by Whitman's departure from Colorado Springs. This narrative is instructive as to what our role should be: to remember, rather than forget, that identities have consequences. Whitman's mythological place as the American poet does not protect him from the fictionalized 
blows that attend the act of outing. Nor should it deter us from recognizing the power of such blows, whether struck in fiction or in fact.

\section{University of California, San Diego}

\section{NOTES}

1 It would be impossible to document all of the publications that take Whitman's sexuality and its impact upon his writing as their primary focus. A cursory view of a bibliography of Whitman criticism from the last ten years would, however, reveal a remarkable increase in such scholarship. The works that in many ways set the stage for this critical resurgence are: Bryne R. S. Fone, Masculine Landscapes: Walt Whitman and the Homoerotic Text (Carbondale: Southern Illinois University Press, 1992); M. Jimmie Killingsworth, Whitman's Poetry of the Body: Sexuality, Politics, and the Text (Chapel Hill: University of North Carolina Press, 1989); and Michael Moon, Disseminating Whitman: Revision and Corporeality in 'Leaves of Grass' (Cambridge: Harvard University Press, 1991).

2 Gary Schmidgall, Walt Whitman: A Gay Life (New York: Plume, 1997), 352.

3 In a previous episode, the local library comes under public scrutiny for containing lewd literature, including Whitman's poetry. Dr. Quinn defends freedom of expression and the library's right to contain his writing.

4 My description of the episode, as well as all quotes, are based upon my viewing of the episode, as well as on a copy of the script available on the internet. Christine Berardo, "The Body Electric" (April 1997), The Official Dr. Quinn, Medicine Woman Website (May 1998).

5 Eve Sedgwick, Epistemology of the Closet (Los Angeles: University of California Press, 1990), 79-81.

6 Leaves of Grass: A Textual Variorum, 3 vols., ed. Sculley Bradley, Harold W. Blodgett, Arthur Golden, and William White (New York: New York University Press, 1980), 1:238. All subsequent citations of Whitman's poetry are to this edition. 